\title{
PENGARUH INVESTMENT OPPORTUNITY SET DAN FREE CASH FLOW PADA KEBIJAKAN DIVIDEN DAN NILAI PERUSAHAAN
}

\author{
I Gst. Ngr. Putu Adi Suartawan ${ }^{1}$ \\ Gerianta Wirawan Yasa ${ }^{2}$ \\ ${ }^{1,2}$ Fakultas Ekonomi dan Bisnis, Universitas Udayana, Bali, Indonesia \\ email: adi.ign8@gmail.com
}

\begin{abstract}
ABSTRAK
Penelitian ini bertujuan untuk mengetahui pengaruh investment opportunity set dan free cash flow pada kebijakan dividen serta implikasinya pada nilai perusahaan manufaktur yang terdaftar di Bursa Efek Indonesia (BEI) periode 2011-2013. Jumlah sampel yang diambil sebanyak 25 perusahaan, dengan metode penentuan sampel purposive sampling. Pengumpulan data dilakukan melalui observasi non partisipan. Teknik analisis data yang digunakan adalah path analysis yang merupakan perluasan dari teknik analisis regresi linear berganda. Berdasarkan hasil analisis ditemukan bahwa investment opportunity set berpengaruh positif pada kebijakan dividen, menolak hipotesis yang menyatakan arah negatif, free cash flow berpengaruh positif pada kebijakan dividen, investment opportunity set berpengaruh positif pada nilai perusahaan, free cash flow berpengaruh positif pada nilai perusahaan, kebijakan dividen berpengaruh positif pada nilai perusahaan, Investment opportunity set berpengaruh pada nilai perusahaan melalui kebijakan dividen dan free cash flow tidak berpengaruh pada nilai perusahaan melalui kebijakan dividen.
\end{abstract}

Kata kunci: Nilai perusahaan, investment opportunity set, free cash flow, kebijakan dividen

\section{THE EFFECT OF INVESTMENT OPPORTUNITY SET DAN FREE CASH FLOW TOWARDS DIVIDENT POLICY AND FIRM VALUE ABSTRACT}

\begin{abstract}
This research is conducted to find out the effect of investment opportunity set and free cash flow towards dividend policy and its impacts on firm value of manufacturing companies registered in Indonesia Stock Exchange during the period of 2011-2013. The samples of this study are 25 manufacturing companies and they were selected by using purposive sampling method. The data is collected through non participants' observation. Path analysis which is an extension of the multiple linear regression technique is used to analyze data. Based on the data analysis, it was found that, investment opportunity set has positive effects on dividend policy. It refuses the negative hypothesis, free cash flow has positive effects on dividend policy, investment opportunity set has positive effects on firm value, free cash flow has positive effects on firm value, dividend policy has positive effects on firm value, investment opportunity set has effects on firm value through dividend policy and free cash flow has no effects on firm value through dividend policy.
\end{abstract}

Keywords: Firm value, investment opportunity set, free cash flow, dividend policy

DOI : https://doi.org/10.24843/JIAB.2016.v11.i02.p01

\section{PENDAHULUAN}

Dewasa ini pertumbuhan ekonomi dunia berpengaruh pada melemahnya aktivitas bisnis secara umum yang disebabkan oleh global financial crisis pada tahun 2008. Di Indonesia pertumbuhan perusahaan manufaktur sangat berperan penting dalam pertumbuhan ekonomi negara, karena sektor manufaktur di Indonesia memiliki jumlah perusahaan terbanyak dibandingkan dengan sektor lainnya. Fakta yang terlihat bahwa kondisi pertumbuhan pada perusahaan manufaktur di Bursa Efek Indonesia (BEI) dalam data Badan Pusat Statistik (BPS) yang khususnya ditunjukkan pada pertumbuhan industri besar dan sedang mengalami petumbuhan setiap tahunnya.

Pada tahun 2011 hingga tahun 2013 pertumbuhan industri di Indonesia mengalami trend yang positif yaitu pada tahun 2011 mengalami kenaikan sebesar $4,34 \%$ dari tahun sebelumnya. Pertumbuhan industri tahun 2012 mengalami kenaikan sebesar 4,93\% dari tahun 2011, kemudian pada tahun 2013 pertumbuhan perusahaan manufaktur juga mengalami peningkatan sebesar $5,81 \%$ dari tahun sebelumnya.

Tingkat pertumbuhan perusahaan manufaktur dalam pasar modal menjadi salah satu perhatian 
penting bagi investor. Berdasarkan laporan keuangan perusahaan, investor dapat melakukan analisis atas laporan keuangan yang bertujuan untuk meningkatkan pengambilan keputusan bisnis dengan mengevaluasi informasi yang tersedia tentang situasi keuangan perusahaan, manajemen, strategi dan lingkungan bisnisnya. Investor memerlukan informasi keuangan perusahaan yang akurat dalam memperoleh gambaran tentang kondisi perusahaan secara menyeluruh. Oleh karena itu, perusahaan dituntut untuk selalu meningkatkan kinerjanya, sehingga dapat meningkatkan nilai perusahaan.

Optimalisasi nilai perusahaan merupakan tujuan perusahaan dapat dicapai melalui pelaksanaan fungsi manajemen keuangan. Keputusan keuangan akan memengaruhi keputusan keuangan lainnya, sehingga akan berdampak pada nilai perusahaan. Keputusan penting dalam perusahaan dapat berkaitan dengan investment opportunity set, free cash flow dan kebijakan dividen (Wright dan Ferris, 1997 dalam Hasnawati, 2005). Untuk mencapai tujuan perusahaan tersebut, shareholder akan menyerahkan pengelolaan perusahaan kepada manajer perusahaan. Di dalam proses pendelegasian wewenang ini, sering dijumpai beberapa persoalan yang berhubungan dengan konflik di antara manajer dengan shareholder (agency conflict), dimana manajer berfungsi sebagai agent dan shareholder sebagai principal.

Investment Opportunity Set (IOS) merupakan kesempatan investasi yang besarnya tergantung pada pengeluaran yang ditetapkan oleh manajemen pada masa yang akan datang, dan merupakan investasi yang diharapkan untuk mendapatkan return yang lebih besar (Julianto dan Lilis, 2004 dalam Fidhayatin dan Dewi, 2012). Myers (1977) dalam Delira (2007) memperkenalkan IOS untuk mencapai tujuan perusahaan. Nilai perusahaan dibentuk melalui indikator nilai pasar saham sangat dipengaruhi oleh peluang-peluang investasi. Secara umum IOS menggambarkan tentang luasnya kesempatan atau peluang-peluang investasi suatu perusahaan namun sangat tergantung pada pilihan pengeluaran perusahaan untuk kepentingan di masa mendatang.

Penelitian yang dilakukan oleh Rizqia, dkk (2013) menunjukkan bahwa Investment Opportunity Set (IOS) berpengaruh positif dan signifikan pada nilai perusahaan. Penelitian Pratiska (2013) menemukan bahwa IOS berpengaruh positif dan signifikan pada nilai perusahaan. Keputusan investasi dibuat oleh manajemen akan memengaruhi cara pandang investor dan pemilik perusahaan sehingga memengaruhi nilai perusahaan. Pengaruh IOS pada nilai perusahaan didasarkan pada signaling theory. Perusahaan akan memberikan sinyal positif terhadap investor, sehingga investor akan memberikan respon positif terhadap perusahaan memiliki IOS tinggi. IOS tinggi akan menjanjikan return lebih tinggi di masa mendatang. Investor yang menyukai risiko (risk seeker) telah mengerti atau memahami bahwa return tinggi akan diikuti dengan tingkat risiko tinggi.

Kepercayaan investor terhadap perusahaan yang disertai keputusan investasi, menyebabkan naiknya permintaan terhadap saham perusahaan. Peluang investasi memberikan sinyal positif tentang pertumbuhan perusahaan di masa mendatang. Hal ini akan meningkatkan harga saham sebagai indikator nilai perusahaan. Sebaliknya, Penelitian Kallapur dan Trombley (1999) dan Suharli (2007) menemukan bahwa investment opportunity set tidak berpengaruh signifikan pada nilai perusahaan.

Faktor lain yang memengaruhi nilai perusahaan adalah free cash flow (Andini dan Wirawati, 2014). Free cash flow dapat diartikan adanya dana berlebih yang seharusnya dapat didistribusikan kepada para pemegang saham, namun keputusan tersebut dipengaruhi oleh kebijakan manajemen (Arieska dan Gunawan, 2011). Jensen (1986) berpendapat bahwa terlalu banyak free cash flow akan mengakibatkan ketidakcukupan internal dan pemborosan sumber daya perusahaan, sehingga mengarah ke biaya agensi sebagai beban dari pemegang saham.

Penelitian Wang (2010) pada perusahaan go public di Taiwan menunjukkan bahwa free cash flow berpengaruh positif pada kinerja perusahaan. Artinya, semakin tinggi free cash flow perusahaan, maka kinerja perusahaan akan semakin baik. Penelitian Gregory dan Wang (2010) di Inggris menemukan bahwa perusahaan memiliki free cash flow tinggi menghasilkan return lebih baik daripada perusahaan dengan free cash flow rendah. Free cash flow yang tinggi pada perusahaan hanya dapat menjadi masalah ketika perusahaan memiliki sedikit kesempatan investasi. Kondisi seperti itu akan membuat manajer tertarik untuk menggunakan free cash flow yang tidak menguntungkan perusahaan (Jensen, 1988). Studi yang dilakukan oleh Szewcyzk et al. (1996), Chang et. al., (2007), serta Wang (2010), menemukan bukti empiris bahwa investor akan mendukung perusahaan memiliki substansial free cash flow dan kesempatan investasi menguntungkan di dalam valuasi saham.

Hasil berbeda ditunjukan oleh penelitian Embara, dkk (2012) bahwa free cash flow tidak berpengaruh signifikan pada harga saham. Hal ini berarti bahwa besar kecilnya free cash flow yang dimiliki oleh suatu 
perusahaan tidak direspon oleh pasar sehingga tidak berdampak langsung pada harga saham.

Berdasarkan beberapa hasil penelitian di atas, terdapat ketidakkonsistenan hasil penelitian. Oleh karena itu, penelitian ini menguji kembali pengaruh investment opportunity set dan free cash flow pada nilai perusahaan dengan mengoperasionalkan kebijakan dividen sebagai pemediasi. Kebijakan dividen dipilih sebagai variabel mediasi karena menjadi pusat perhatian banyak pihak seperti pemegang saham, kreditor, maupun pihak eksternal lain yang memiliki kepentingan dari informasi yang dikeluarkan perusahaan (Kartika, 2005 dalam Erlangga, 2009). Dividen mengandung informasi sebagai syarat prospek perusahaan. Semakin besar dividen dibagikan kepada pemegang saham, maka kinerja perusahaan akan dianggap semakin baik, dan pada akhirnya penilaian terhadap perusahaan tercermin melalui harga saham akan semakin baik pula (Rozeff, 1982 dalam Erlangga, 2009).

Ada beberapa teori berkenaan dengan pengaruh antara kebijakan dividen dengan nilai perusahaan, diantaranya adalah teori ketidakrelevanan dividen (dividend irrelevance theory) dan bird in the hand theory, yang keduanya saling bertentangan. Menurut dividend irrelevance theory yang diajukan oleh Miller dan Modigliani (1961) dalam Brigham dan Houston (2001:66), dikatakan bahwa kebijakan dividen tidak mempunyai pengaruh baik pada nilai perusahaan maupun biaya modalnya. Miller dan Modigliani berpendapat bahwa nilai suatu perusahaan tergantung semata-mata pada pendapatan yang dihasilkan oleh aset, bukan pada bagaimana pendapatan tersebut dibagi sebagai dividen.

Berbeda dengan irrelevance theory, menurut bird in the hand theory yang diajukan oleh Lintner dan Gordon (1962) dalam Brigham dan Houston (2001:67), menyatakan nilai perusahaan akan dimaksimumkan oleh rasio pembayaran dividen yang tinggi. Teori ini berpendapat bahwa investor menyukai dividen karena kas di tangan lebih bernilai daripada kekayaan dalam bentuk lain. Konsekuensinya, harga saham perusahaan akan sangat ditentukan oleh besarnya dividen yang dibagikan. Peningkatan dividen akan meningkatkan harga saham dan berdampak pula pada nilai perusahaan.

Pada sisi lain, Amihud dan Li (2002) menyatakan adanya kecenderungan di Amerika dimana terjadi penurunan reaksi harga saham terhadap pengumuman pembayaran dividen sejak pertengahan tahun 1978. Hal ini mengindikasikan bahwa kebijakan dividen semakin berkurang kandungan informasinya sehingga disebut sebagai disappearing dividend.

Menurut Brigham dan Houston (2001:221), selama satu tahun mungkin perusahaan membayarkan nol dividen. Hal tersebut disebabkan perusahaan membutuhkan uang guna mendanai peluang investasi yang baik, tetapi pada tahun berikutnya perusahaan akan membayarkan dividen dalam jumlah besar karena peluang investasi yang buruk dan tidak perlu menahan banyak uang. Hal ini sesuai dengan Suharli (2007) yang menyatakan apabila kondisi perusahaan sangat baik maka pihak manajemen akan cenderung lebih memilih investasi baru daripada membayar dividen yang tinggi (agency theory). Dana yang seharusnya dapat dibayarkan sebagai dividen kepada pemegang saham akan digunakan untuk pembelian investasi yang menguntungkan.

$\mathrm{H}_{1}$ : Investment opportunity set berpengaruh negatif pada kebijakan dividen.

Berdasarkan agency theory, perusahaan yang memiliki free cash flow tinggi akan membagikan dividen dalam jumlah yang tinggi pula. Hal ini dikarenakan adanya tekanan dari pihak pemegang saham untuk membagikannya dalam bentuk dividen (Mollah, 2011 dalam Puspitasari dan Darsono, 2014). Pemegang saham yakin bahwa dividen yang dibagikan akan mempunyai nilai lebih tinggi dan risiko lebih rendah dibandingkan pendapatan modal. Dengan kata lain, investor lebih menyukai dividen karena kas di tangan lebih bernilai daripada kekayaan dalam bentuk lain. Hasil pengujian dilakukan Thanatawee (2011) dan Rosdini (2009) menemukan bahwa free cash flow berpengaruh positif pada dividend payout ratio.

$\mathrm{H}_{2}$ : Free cash flow berpengaruh positif pada kebijakan dividen.

Myers (1997) dalam Hasnawati (2005) menyebutkan bahwa investment opportunity set dalam kaitannya untuk mencapai tujuan perusahaan, memberikan petunjuk yang lebih luas dimana nilai perusahaan sebagai tujuan utama tergantung pada pengeluaran perusahaan di masa mendatang. Untuk mencapai tujuan perusahaan yaitu maksimalisasi nilai perusahaan, manajer membuat keputusan investasi guna menghasilkan net present value positif (Modigliani dan Miller, 1961 dalam Brigham dan Houston, 2001). Penelitian yang dilakukan oleh Fahrizal (2013) dan Astriani (2014) menunjukkan bahwa investment opportunity set berpengaruh positif pada nilai perusahaan. 
$\mathrm{H}_{3}$ : Investment opportunity set berpengaruh positif pada nilai perusahaan.

Free cash flow mencerminkan keleluasaan perusahaan dalam melakukan investasi tambahan, melunasi hutang, membeli saham treasury atau menambah likuiditas. Free cash flow tinggi mengindikasikan kinerja perusahaan tinggi, sehingga nilai perusahaan akan meningkat. Kinerja perusahaan yang tinggi akan meningkatkan nilai pemegang saham yang diwujudkan dalam bentuk return yang tinggi melalui dividen, harga saham, atau laba ditahan untuk diinvestasikan di masa depan. Penelitian yang dilakukan oleh Andini dan Wirawati (2014) menunjukkan bahwa free cash flow berpengaruh positif dan signifikan pada nilai perusahaan. Hasil ini sejalan dengan penelitian yang dilakukan oleh Vogt dan Vu (2000).

$\mathrm{H}_{4}$ : Free cash flow berpengaruh positif pada nilai perusahaan.

Kebijakan dividen menyangkut keputusan tentang penggunaan laba yang menjadi hak pemegang saham. Penelitian Wijaya dan Wibawa (2010) serta Fenandar dan Raharja (2012) dapat membuktikan bahwa kebijakan dividen memengaruhi nilai perusahaan secara positif dan mendukung bird in the hand theory.

$\mathrm{H}_{5}$ : Kebijakan dividen berpengaruh positif pada nilai perusahaan.

Investment opportunity set menunjukkan luasnya kesempatan investasi yang dimiliki oleh suatu perusahaan. Apabila kondisi perusahaan saat baik maka pihak manajemen akan cenderung lebih memilih investasi baru daripada membayar dividen yang tinggi. Ketika perusahaan memilih untuk mengurangi rasio pembayaran dividen, atau bahkan tidak membagikan dividen maka investor akan enggan berinvestasi pada perusahaan yang bersangkutan sehingga dapat menurunkan nilai perusahaan. Begitu pula sebaliknya ketika perusahaan memilih untuk membagikan dividen dalam jumlah yang tinggi dibandingkan membiayai suatu investasi baru, maka investor akan merespon positif informasi tersebut sehingga berdampak pada peningkatan nilai perusahaan. $\mathrm{H}_{6}$ : Investment opportunity set berpengaruh pada nilai perusahaan melalui kebijakan dividen

Ketika free cash flow tinggi, maka perusahaan akan cenderung membagikannya ke dalam bentuk dividen. Dividen yang dibagikan oleh perusahaan akan memberikan sinyal positif bagi investor sehingga dapat meningkatkan nilai perusahaan. Apabila free cash flow perusahaan tinggi tetapi perusahaan tidak membagikan dividen, maka investor akan mempertanyakan aliran kas tersebut sehingga menimbulkan sinyal negatif bagi pasar dan berdampak pada penurunan nilai perusahaan.

$\mathrm{H}_{7}$ : Free cash flow berpengaruh pada nilai perusahaan melalui kebijakan dividen.

\section{METODE PENELITIAN}

Penelitian ini menggunakan pendekatan kuantitatif yang berbentuk asosiatif. Desain penelitian menunjukkan pengaruh langsung antara investment opportunity set $\left(\mathrm{X}_{1}\right)$ dengan kebijakan dividen $\left(\mathrm{Y}_{1}\right)$, free cash flow $\left(\mathrm{X}_{2}\right)$ dengan kebijakan dividen $\left(\mathrm{Y}_{1}\right)$, investment opportunity set $\left(\mathrm{X}_{1}\right)$ dengan nilai perusahaan $\left(\mathrm{Y}_{2}\right)$, free cash flow $\left(\mathrm{X}_{2}\right)$ dengan nilai perusahaan $\left(\mathrm{Y}_{2}\right)$, dan kebijakan dividen $\left(\mathrm{Y}_{1}\right)$ dengan nilai perusahaan $\left(\mathrm{Y}_{2}\right)$. Selain itu, ditunjukkan pula pengaruh investment opportunity set $\left(\mathrm{X}_{1}\right)$ dengan nilai perusahaan $\left(\mathrm{Y}_{2}\right)$ melalui kebijakan dividen $\left(\mathrm{Y}_{1}\right)$ dan pengaruh free cash flow $\left(\mathrm{X}_{2}\right)$ pada nilai perusahaan $\left(\mathrm{Y}_{2}\right)$ melalui kebijakan dividen $\left(\mathrm{Y}_{1}\right)$.

Penelitian ini dilakukan pada perusahaan manufaktur yang terdaftar di Bursa Efek Indonesia tahun 2011-2013 dengan mengakses www.idx.co.id dan Indonesian Capital Market Directory (ICMD). Jenis data yang digunakan adalah data kuantitatif, dengan sumber data sekunder.

Penelitian ini menggunakan tiga variabel penelitian yaitu variabel eksogen berupa investment opportunity set dan free cash flow, variabel endogen berupa nilai perusahaan, dan variabel intervening berupa kebijakan dividen. Investment opportunity set diproksikan dengan Market to Book Value of Equity (Gaver dan Gaver, 1993) yang mencerminkan bahwa pasar menilai return dari investasi perusahaan di masa depan terhadap return yang diharapkan dari ekuitasnya (Hartono, 1998 dalam Wirjono, 2009). Secara matematis Market to Book Value of Equity (MBVE) diformulasikan sebagai berikut (Kallapur dan Trombley, 1999):

MBVE $=\frac{\text { Jumlah Saham Beredar } x \text { Closing Price }}{\text { Total Ekuitas }} \ldots$ (1)

Free cash flow merupakan kelebihan kas yang diperlukan untuk mendanai semua proyek yang memiliki net present value positif setelah membagi dividen (Jensen, 1986). Free cash flow dapat diformulasikan sebagai berikut (Ross et al. 2000):

$$
\text { Free Cash Flow }=\frac{\text { AKO }- \text { PM }- \text { NWC }}{\text { Total Aset }}
$$


Keterangan:

$\mathrm{AKO}=$ Aliran kas operasi perusahaan

PM = Pengeluaran modal bersih perusahaan

NWC $=$ Modal kerja bersih perusahaan

Nilai perusahaan merupakan persepsi investor terhadap tingkat keberhasilan perusahaan dalam mengelola sumber daya pada tahun berjalan. Pada penelitian ini nilai perusahaan diproksikan dengan Tobin's $Q$. Pengukuran kinerja dengan menggunakan Tobin's $Q$ tidak hanya memberikan gambaran pada aspek fundamental saja, tetapi juga sejauh mana pasar menilai perusahaan dari berbagai aspek yang dilihat oleh pihak luar termasuk investor. Tobin's $Q$ mewakili sejumlah variabel yang penting dalam pengukuran kinerja, antara lain aktiva tercatat perusahaan, kecenderungan pasar yang memadai seperti pandangan-pandangan analis mengenai prospek perusahaan, dan variabel modal intelektual atau intangible asset. Tobin's $Q$ dapat diformulasikan sebagai berikut (Chung dan Pruitt, 1994):

$\mathrm{Q}=\frac{M V E+D E B T}{T A}$

Keterangan:

$\mathrm{Q}=$ Nilai perusahaan

MVE = Nilai pasar ekuitas (jumlah saham beredar $\mathrm{X}$ closing price)

DEBT $=($ Utang lancar - aset lancar $)+$ nilai buku persediaan + utang jangka panjang

TA $=$ Nilai buku total aset

Kebijakan dividen pada dasarnya adalah penentuan besarnya porsi keuntungan yang akan dibagikan kepada para pemegang saham. Kebijakan pembayaran dividen merupakan hal penting yang menyangkut apakah arus kas akan dibayarkan kepada investor atau akan ditahan untuk diinvestasikan kembali oleh perusahaan. Dialam penelitian ini, kebijakan dividen diukur dengan Dividend Payout Ratio (DPR) yang dirumuskan sebagai berikut (Wiagustini, 2010:81):

Dividend Payout Ratio $=\frac{\text { Dividend per share }}{\text { Earnings per share }}$
Populasi dalam penelitian ini adalah seluruh perusahaan manufaktur yang terdaftar di Bursa Efek Indonesia periode 2011-2013. Dari jumlah populasi sebanyak 155 perusahaan akan diambil sejumlah tertentu sebagai sampel. Dalam penelitian ini pengambilan sampel menggunakan metode purposive sampling, yaitu teknik pengambilan sampel yang berdasarkan pada kelompok terpilih menurut ciriciri khusus yang dimiliki oleh sampel tersebut. Perusahaan yang memenuhi persyaratan sebagai sampel penelitian berjumlah 30 (tiga puluh) perusahaan manufaktur. Dari jumlah tersebut, terdapat 5 (lima) data bersifat outlier yang harus dikeluarkan dari sampel penelitian, sehingga sampel penelitian berkurang menjadi 25 (dua puluh lima) perusahaan manufaktur.

Metode pengumpulan data yang digunakan dalam penelitian ini adalah metode observasi non partisipan. Data observasi berupa Laporan Tahunan Perusahaan Manufaktur yang terdaftar di Bursa Efek Indonesia (BEI) periode 2011-2013. Teknik analisis data yang digunakan adalah teknik analisis jalur (path analysis). Analisis jalur merupakan perluasan dari analisis regresi linear berganda, untuk menaksir hubungan kausalitas antar variabel yang berjenjang berdasarkan teori yang terdiri dari pengaruh langsung dan tidak langsung (Utama, 2012:156). Persamaan analisis jalur dapat dibentuk sebagai berikut:

$\mathrm{Y}_{1}=\mathrm{b}_{1} \mathrm{Y}_{1} \mathrm{X}_{1}+\mathrm{b}_{2} \mathrm{Y}_{1} \mathrm{X}_{2}+\varepsilon_{1}$

$\mathrm{Y}_{2}=\mathrm{b}_{3} \mathrm{Y}_{2} \mathrm{X}_{1}+\mathrm{b}_{4} \mathrm{Y}_{2} \mathrm{X}_{2}+\mathrm{b}_{5} \mathrm{Y}_{2} \mathrm{Y}_{1}+\varepsilon_{2}$

\section{HASIL DAN PEMBAHASAN}

Statistik deskriptif digunakan untuk memberikan gambaran dan informasi tentang data variabelvariabel penelitian yang meliputi jumlah sampel, nilai minimum, nilai maksimum, nilai rata-rata, dan deviasi standar. Hasil analisis statistik deskriptif pada penelitian ini disajikan pada Tabel 1 .

Berdasarkan Tabel 1 variabel-variabel penelitian yang dijelaskan dalam uji statistik deskriptif adalah sebagai berikut. Variabel nilai perusahaan diproksikan dengan Tobin's $Q$. Tobin's $Q$ merupakan indikator

Tabel 1.

Statistik Deskriptif Variabel Penelitian

\begin{tabular}{|c|c|c|c|c|c|}
\hline Variabel & $\mathrm{N}$ & Minimum & Maksimum & Rata-rata & Deviasi Standar \\
\hline TOBINS Q & 75 & 0,214 & 6,573 & 1,957 & 1,417 \\
\hline MBVE & 75 & 0,410 & 8,994 & 3,072 & 2,035 \\
\hline FCF & 75 & $-0,347$ & 0,300 & $-0,003$ & 0,112 \\
\hline DPR & 75 & 0,034 & 1,897 & 0,400 & 0,278 \\
\hline
\end{tabular}

Sumber: Data diolah, 2015 
yang digunakan untuk mengukur nilai perusahaan yang menunjukkan suatu proforma manajemen dalam mengelola aktiva perusahaan. Nilai Tobin's $Q$ menggambarkan suatu kondisi potensi pertumbuhan perusahaan. Hasil analisis statistik deskriptif menunjukkan Tobin's $Q$ memiliki nilai minimum sebesar 0,2141 dimana nilai ini kurang dari 1 .

Nilai Tobin's $Q$ yang kurang dari 1 menunjukkan adanya harga saham yang undervalued pada perusahaan yang menjadi sampel penelitian, karena nilai pasarnya lebih kecil dari nilai tercatat aset perusahaan. Nilai maksimum sebesar 6,5731 menunjukkan adanya harga saham yang overvalued pada perusahaan yang menjadi sampel penelitian, karena nilai pasarnya lebih besar dari nilai tercatat aset perusahaan (Hasnawati, 2005). Rata-rata sebesar 1,9579 dan deviasi standar sebesar 1,4171 dimana nilai deviasi standar lebih kecil dari nilai rata-ratanya menunjukkan tidak adanya fluktuasi nilai perusahaan yang besar pada perusahaan manufaktur yang menjadi sampel.

Variabel investment opportunity set diproksikan dengan Market to Book Value of Equity (MBVE). MBVE mencerminkan pasar menilai return dari investasi perusahaan di masa depan dari return yang diharapkan dari ekuitasnya. Hasil dari analisis statistik deskriptif menunjukkan MBVE memiliki nilai minimum sebesar 0,4106 . Perusahaan yang memiliki nilai MBVE rendah diindikasikan tidak mampu mengelola modal dengan optimal dalam aktivitas bisnisnya, sehingga growth opportunities perusahaan akan menurun. Nilai maksimum sebesar 8,9941 berarti bahwa perusahaan mengelola modal dengan optimal dalam aktivitas bisnisnya, sehingga growth opportunities perusahaan akan meningkat dimana hal ini dapat ditunjukkan dari peningkatan harga pasar sahamnya (Norpratiwi, 2007 dalam Astriani, 2014). Rata-rata sebesar 3,0721 dan deviasi standar sebesar 2,0352 dimana nilai deviasi standar lebih kecil dari nilai rata-ratanya menunjukkan tidak adanya fluktuasi investment opportunity set yang besar pada perusahaan manufaktur yang menjadi sampel.

Free Cash Flow (FCF) merupakan arus kas yang benar-benar tersedia untuk dibayarkan kepada investor setelah perusahaan melakukan investasi dalam aktiva tetap, produk baru, dan modal kerja yang dibutuhkan untuk mempertahankan operasi berjalan. Hasil dari analisis statistik deskriptif menunjukkan FCF memiliki nilai minimum sebesar $-0,3478$ dimana angka ini bernilai negatif. Terdapat dua kemungkinan terhadap sampel perusahaan yang memiliki nilai FCF negatif yaitu: 1) Jika nilai FCF negatif karena Net Operating Profit After Tax (NOPAT) negatif, maka merupakan suatu hal yang buruk karena menunjukkan perusahaan sedang mengalami masalah operasi; dan 2) Jika nilai FCF negatif, tingkat pertumbuhan perusahaan tinggi, dan NOPAT positif menunjukkan bahwa perusahaan banyak berinvestasi dalam aset operasi untuk mendukung pertumbuhan yang cepat (Husnan, 2002:87). Nilai maksimum sebesar 0,3000 dan bernilai positif menunjukkan bahwa terdapat dana berlebih pada perusahaan yang menjadi sampel penelitian yang dapat digunakan untuk berinvestasi atau dibagikan kepada para pemegang saham. Ratarata sebesar -0,0034 dan deviasi standar sebesar 0,1124 dimana nilai deviasi standar lebih besar dari nilai rata-ratanya menunjukkan adanya fluktuasi free cash flow yang besar pada perusahaan manufaktur yang menjadi sampel.

Variabel kebijakan dividen diproksikan dengan Dividend Payout Ratio (DPR). DPR merupakan persentase dari pendapatan yang akan dibayarkan kepada pemegang saham sebagai cash dividend. Hasil dari analisis statistik deskriptif menunjukkan DPR memiliki nilai minimum sebesar 0,0349 yang berarti bahwa, dari total laba bersih yang dihasilkan oleh perusahaan sampel, yang dibagikan dalam bentuk dividen kepada pemegang saham hanya sebesar 3,49 persennya, dimana nilai ini jauh lebih kecil dibandingkan dengan nilai rata-rata DPR sampel yang bernilai 40,08 persen. Nilai maksimum sebesar 1,8979 berarti bahwa, dari total laba bersih yang dihasilkan oleh perusahaan sampel, yang dibagikan dalam bentuk dividen kepada pemegang saham sebesar 189,79 persennya, dimana nilai ini jauh lebih besar dibandingkan dengan nilai rataratanya. Rata-rata sebesar 0,4008 dan deviasi standar sebesar 0,2789 dimana nilai deviasi standar lebih kecil dari nilai rata-ratanya menunjukkan tidak adanya fluktuasi kebijakan dividen yang besar pada perusahaan manufaktur yang menjadi sampel.

Tabel 2.

Hasil Uji Normalitas

\begin{tabular}{|c|c|}
\hline Kolmogorov-Smirnov $Z$ & Unstandardized Residual \\
\hline $\mathrm{N}$ & 75 \\
\hline Asymp. Sig & 0,321 \\
\hline
\end{tabular}


Hasil pengujian statistik dengan menggunakan Statistical Product and Service Solutions (SPSS) menunjukkan bahwa variabel Tobin's $Q$, Market to Book Value of Equity (MBVE), Free Cash Flow (FCF), Dividend Payout Ratio (DPR) dan residual model yang dibuat telah berdistribusi normal. Hal ini ditunjukkan oleh nilai Asymp. Sig $(0,321)$ yang lebih besar dari 0,05. Dengan demikian, model yang dibuat pantas digunakan untuk analisis lebih lanjut.

Tabel 3.

\begin{tabular}{cc}
\multicolumn{2}{c}{ Hasil Uji Autokorelasi } \\
\hline Model & Durbin-Watson \\
\hline 1 & 1,822 \\
\hline \multicolumn{2}{l}{ Sumber: } \\
\hline
\end{tabular}

Dengan level of significant sebesar 5 persen, $\mathrm{n}=75$, dan jumlah variabel bebas (k') sebanyak 3, maka diperoleh nilai $\mathrm{d}_{\mathrm{L}}=1,54$ dan $\mathrm{d}_{\mathrm{U}}=1,71$ (Lampiran 3). Oleh karena nilai Durbin-Watson sebesar 1,822 lebih besar dari batas atas $\left(\mathrm{d}_{\mathrm{U}}\right)$ yakni 1,71 dan kurang dari 2,29 $\left(4-\mathrm{d}_{\mathrm{U}}\right)$, maka dapat disimpulkan bahwa d statistik berada pada daerah tidak ada autokorelasi atau model regresi yang dibuat tidak mengandung gejala autokorelasi, sehingga layak digunakan untuk memprediksi.

\section{Tabel 4.}

\section{Hasil Uji Multikolinearitas}

\begin{tabular}{lcc}
\hline \multicolumn{1}{c}{ Variabel } & Tolerance & VIF \\
\hline MBVE & 0,911 & 1,098 \\
FCF & 0,802 & 1,247 \\
DPR & 0,751 & 1,332 \\
\hline
\end{tabular}

Sumber: Data diolah, 2015

Berdasarkan Tabel 4 diketahui bahwa nilai tolerance semua variabel eksogen lebih besar dari 0,10 dan nilai VIF semua variabel eksogen lebih kecil dari 10,00. Dengan demikian, dapat disimpulkan bahwa tidak terdapat gejala multikolinearitas dari model regresi yang dibuat, sehingga model tersebut layak digunakan untuk memprediksi.
Tabel 5.

Hasil Uji Heteroskedastisitas

\begin{tabular}{lcc}
\hline \multicolumn{1}{c}{ Variabel } & Sig. & Keterangan \\
\hline MBVE & 0,065 & Bebas heteroskedastisitas \\
FCF & 0,095 & Bebas heteroskedastisitas \\
DPR & 0,765 & Bebas heteroskedastisitas \\
\hline
\end{tabular}

Sumber: Data diolah, 2015

Berdasarkan Tabel 5 terlihat bahwa nilai sig. pada masing-masing variabel berada di atas 0,05. Dengan demikian, model yang dibuat tidak mengandung gejala heteroskedastisitas, sehingga layak digunakan untuk memprediksi.

Dalam menguji validitas model pada analisis jalur digunakan koefisien determinasi total yang diukur dengan:

$$
\begin{aligned}
P_{e 1} & =\sqrt{1-\mathrm{R}^{2}} \\
& =\sqrt{1-0,249} \\
& =0,751 \\
P_{e 2} & =\sqrt{1-\mathrm{R}^{2}} \\
& =\sqrt{1-0,681} \\
& =0,319 \\
\mathrm{R}^{2} & =1-\left(\hat{y}_{1}, \hat{y}_{1}\right) \\
& =1-\left(0,751^{2} \times 0,319^{2}\right) \\
& =0,943
\end{aligned}
$$

Koefisien determinasi total persamaan struktural dari model penelitian sesuai dengan perhitungan diperoleh nilai $\mathrm{R}_{\mathrm{m}}^{2}=0,943$. Koefisien determinasi total sebesar 0,943 mempunyai arti bahwa sebesar 94,3 persen informasi yang terkandung dapat dijelaskan oleh model yang dibentuk, sedangkan sisanya, yaitu 5,7 persen dijelaskan oleh variabel lain di luar model yang dibentuk. $P_{e i}$ merupakan standard error of estimate dari model regresi. $P_{e l}$ sebesar 0,751 berarti bahwa banyaknya kesalahan dalam prediksi kebijakan dividen sebesar 75,1 persen. $P_{e 2}$ sebesar 0,319 berarti bahwa banyaknya kesalahan dalam prediksi nilai perusahaan sebesar 31,9 persen.

Tabel 6.

Ringkasan Koefisien Jalur

\begin{tabular}{lccccc}
\hline \multicolumn{1}{c}{ Regresi } & $\begin{array}{c}\text { Koef. Reg. } \\
\text { Standar }\end{array}$ & $\begin{array}{c}\text { Standard } \\
\text { Error }\end{array}$ & t Hitung & P. Value & Keterangan \\
\hline $\mathrm{MBVE} \rightarrow \mathrm{DPR}$ & 0,232 & 0,014 & 2,243 & 0,028 & Signifikan \\
$\mathrm{FCF} \rightarrow$ DPR & 0,407 & 0,257 & 3,937 & 0,000 & Signifikan \\
$\mathrm{MBVE} \rightarrow \mathrm{Q}$ & 0,786 & 0,047 & 11,611 & 0,000 & Signifikan \\
$\mathrm{FCF} \rightarrow \mathrm{Q}$ & 0,150 & 0,854 & 2,222 & 0,029 & Signifikan \\
$\mathrm{DPR} \rightarrow \mathrm{Q}$ & 0,258 & 0,575 & 2,286 & 0,025 & Signifikan \\
\hline
\end{tabular}

Sumber: Data diolah, 2015 
Berdasarkan hasil yang diperoleh dari hasil analisis jalur, maka model persamaan yang dapat dibentuk adalah sebagai berikut:

$\mathrm{DIV}=0,232 \mathrm{IOS}+0,407 \mathrm{FCF}+\varepsilon_{1}$ $\mathrm{NP}=0,799 \mathrm{IOS}+0,173 \mathrm{FCF}+0,258 \mathrm{DIV}+\varepsilon_{2}$

Keterangan:

$\mathrm{NP}=$ Nilai Perusahaan

DIV $=$ Kebijakan Dividen

IOS = Investment Opportunity Set

$\mathrm{FCF}=$ Free Cash Flow

Dalam menguji pengaruh kebijakan dividen dalam memediasi pengaruh investment opportunity set pada nilai perusahaan maka diperoleh: $\mathrm{b}_{1}=0,232$; $\mathrm{b}_{5}=0,258 ; \mathrm{Sb}_{1}=0,014 ;$ dan $\mathrm{Sb}_{5}=0,575$. Pengaruh mediasi yang ditunjukkan oleh perkalian koefisien $\left(b_{1} b_{5}\right)$ diuji dengan Sobel Test sebagai berikut.

$$
\begin{aligned}
\mathrm{Sb}_{1} \mathrm{~b}_{5} & =\sqrt{\mathrm{b}_{5}{ }^{2} \mathrm{Sb}_{1}{ }^{2}+\mathrm{b}_{1}{ }^{2} \mathrm{Sb}_{5}{ }^{2}+\mathrm{Sb}_{1}{ }^{2} \mathrm{Sb}_{5}{ }^{2}} \\
& =\sqrt{\left(0,258^{2} \times 0,014^{2}\right)+\left(0,232^{2} \times 0,575^{2}\right)+\left(0,014^{2} \times 0,575^{2}\right)} \\
& =0,021472362
\end{aligned}
$$

Untuk menghitung t statistik pengaruh mediasi menggunakan rumus berikut:

$$
\begin{aligned}
t & =\frac{\mathrm{b}_{1} \mathrm{~b}_{5}}{\mathrm{Sb}_{1} \mathrm{~b}_{5}} \\
& =\frac{0,059856}{0,021472362} \\
& =2,787583406 \\
& =2,788 \text { (dibulatkan) }
\end{aligned}
$$

Dengan tingkat signifikansi sebesar 0,050 dan degree of freedom $(\mathrm{df})=72$ maka t tabel $=1,666$. Dari perhitungan di atas dapat disimpulkan bahwa $t$ hitung $(2,788)$ lebih besar dari t tabel $(1,666)$, sehingga kebijakan dividen dapat memediasi pengaruh investment opportunity set pada nilai perusahaan.

Di dalam menguji pengaruh kebijakan dividen dalam memediasi pengaruh free cash flow pada nilai perusahaan maka diperoleh: $b_{2}=0,407 ; \mathrm{Sb}_{2}=0,257$. Pengaruh mediasi yang ditunjukkan oleh perkalian koefisien $\left(\mathrm{b}_{2} \mathrm{~b}_{5}\right)$ diuji dengan Sobel Test sebagai berikut:

$$
\begin{aligned}
\mathrm{Sb}_{2} \mathrm{~b}_{5} & =\sqrt{\mathrm{b}_{5}{ }^{2} \mathrm{Sb}_{2}{ }^{2}+\mathrm{b}_{2}{ }^{2} \mathrm{Sb}_{5}{ }^{2}+\mathrm{Sb}_{2}{ }^{2} \mathrm{Sb}_{5}{ }^{2}} \\
& =\sqrt{\left(0,258^{2} \times 0,257^{2}\right)+\left(0,407^{2} \times 0,575^{2}\right)+\left(0,257^{2} \times 0,575^{2}\right)} \\
& =0,142911151
\end{aligned}
$$

Untuk menghitung t statistik pengaruh mediasi menggunakan rumus berikut:

$$
\begin{aligned}
\mathrm{t} & =\frac{\mathrm{b}_{2} \mathrm{~b}_{5}}{\mathrm{Sb}_{2} \mathrm{~b}_{5}} \\
& =\frac{0,105006}{0,142911151} \\
& =0,734764217 \\
& =0,735 \text { (dibulatkan) }
\end{aligned}
$$

Dengan tingkat signifikansi sebesar 0,050 dan degree of freedom $(\mathrm{df})=71$ maka $\mathrm{t}$ tabel $=1,667$. Dari perhitungan di atas dapat disimpulkan bahwa $t$ hitung $(0,735)$ lebih kecil dari t tabel $(1,667)$, sehingga kebijakan dividen tidak dapat memediasi pengaruh free cash flow pada nilai perusahaan.

Hasil uji pada Tabel 6 menunjukkan bahwa taraf signifikansi pengaruh investment opportunity set pada kebijakan dividen sebesar 0,028 $<0,050$ dan koefisien regresi sebesar 0,232 dengan arah positif, sementara hipotesis menyatakan arah negatif. Hasil penelitian ini menolak hipotesis pertama. Hal ini menunjukkan bahwa semakin meningkat nilai IOS maka akan menyebabkan pembayaran dividen yang juga meningkat, demikian juga sebaliknya. Hasil penelitian ini mengindikasikan bahwa dana yang dimiliki oleh perusahaan manufaktur mampu untuk membiayai investasi perusahaan dan membagikan dividen pada saat yang bersamaan. Secara umum, investor di Indonesia lebih menyukai adanya pembagian dividen karena kas di tangan lebih bernilai daripada kekayaan dalam bentuk lain, sehingga perusahaan dapat mengambil kesempatan investasi sejalan dengan pembagian dividen.

Berdasarkan Tabel 6 menunjukkan bahwa koefisien regresi dari free cash flow pada kebijakan dividen adalah sebesar 0,407 dengan taraf signifikansi $0,000<0,050$. Hasil penelitian ini menerima hipotesis kedua. Semakin tinggi free cash flow maka semakin tinggi pula pembayaran dividen, atau sebaliknya. Crutchley dan Hansen (1989) melalui penelitiannya menyatakan bahwa perusahaan dapat mendistribusikan free cash flow kepada para pemegang saham dengan melakukan pembayaran dividen untuk menghindari penyalah gunaan free cash flow tersebut. Tekanan pasar akan mendorong manajer untuk mendistribusikan free cash flow kepada pemegang saham (Jensen, 1986).

Tabel 6 menunjukkan bahwa koefisien regresi dari investment opportunity set pada nilai perusahaan adalah sebesar 0,799 dengan taraf signifikansi 0,000 $<0,050$. Hasil penelitian ini menerima hipotesis 
ketiga. Semakin tinggi IOS maka perusahaan akan memiliki nilai di masa yang akan datang dan akan dinilai tinggi oleh investor, demikian juga sebaliknya. Penelitian ini mendukung signaling theory yang menyatakan bahwa pengeluaran investasi memberikan sinyal positif mengenai pertumbuhan perusahaan di masa yang akan datang, sehingga dapat meningkatkan harga saham yang digunakan sebagai indikator penilaian terhadap nilai perusahaan (Wahyudi dan Pawestri, 2006). Keputusan investasi yang dilakukan suatu perusahaan mengandung informasi yang berisi sinyal-sinyal akan prospek perusahaan. Kepercayaan investor terhadap perusahaan manufaktur yang memiliki keputusan investasi tinggi pada saat ini, menyebabkan naiknya permintaan terhadap saham perusahaan manufaktur di Indonesia.

Hasil uji pada Tabel 6 menunjukkan bahwa koefisien regresi dari free cash flow pada nilai perusahaan adalah sebesar 0,173 dengan taraf signifikansi $0,024<0,050$. Hasil penelitian ini menerima hipotesis keempat. Hal ini menunjukkan bahwa semakin besar free cash flow yang terdapat dalam suatu perusahaan, maka semakin tinggi nilai perusahaan, demikian juga sebaliknya. Hasil ini sejalan dengan penelitian yang dilakukan oleh Vogt dan $\mathrm{Vu}$ (2000), di mana perusahaan dengan tingkat free cash flow yang paling tinggi akan memiliki return yang lebih besar daripada perusahaan dengan free cash flow yang rendah. Free cash flow mencerminkan kas yang benar-benar tersedia dan tidak digunakan untuk membiayai kegiatan operasional perusahaan. Oleh karena itu, manajer membuat perusahaan menjadi lebih bernilai dengan meningkatkan free cash flow (Husnan, 2002). Selain itu, free cash flow harus dibayarkan kepada pemegang saham dalam bentuk dividen jika perusahaan ingin memaksimalkan nilainya, karena hal tersebut akan dianggap sebagai sinyal positif bagi para investor.

Berdasarkan Tabel 6 menunjukkan bahwa koefisien regresi dari kebijakan dividen pada nilai perusahaan adalah sebesar 0,258 dengan taraf signifikansi $0,025<0,050$. Hasil penelitian ini menerima hipotesis kelima. Hal ini berarti semakin tinggi pembagian dividen maka nilai perusahaan akan semakin tinggi, atau sebaliknya. Hasil penelitian mendukung bird in the hand theory yang menyatakan bahwa investor lebih menyukai perusahaan yang membagikan dividen karena adanya kepastian tentang return investasi serta dapat mengantisipasi risiko ketidakpastian tentang kebangkrutan perusahaan (Sugiarto, 2011). Selain itu, pembagian dividen lebih kecil risikonya dibandingkan dengan capital gain sehingga pembayaran dividen yang tinggi akan meminimumkan biaya modal yang pada gilirannya akan meningkatkan nilai perusahaan. Hasil penelitian ini juga mendukung hasil penelitian Fenandar dan Raharja (2012), Wijaya dan Wibawa (2010) serta Sujoko dan Soebiantoro (2007).

Berdasarkan Sobel Test menunjukkan bahwa nilai t hitung $(2,788)$ lebih besar dari t tabel $(1,666)$. Hasil penelitian ini menerima hipotesis keenam. Sesuai dengan ketentuan Baron dan Kenny (1986) dalam Fahmi, dkk (2014), diperoleh bahwa: 1) Investment opportunity set berpengaruh positif pada nilai perusahaan; 2) Investment opportunity set berpengaruh positif pada kebijakan dividen; dan 3) Kebijakan dividen berpengaruh positif pada nilai perusahaan. Dengan demikian kebijakan dividen memediasi pengaruh investment opportunity set pada nilai perusahaan secara parsial. Hasil penelitian ini mengindikasikan bahwa investasi yang dilakukan perusahaan manufaktur memberikan tingkat keuntungan yang baik sehingga perusahaan dapat membagikan dividen yang tinggi. Ketika perusahaan mampu berinvestasi dengan baik dan kemudian mampu membagikan dividen kepada para pemegang saham, maka hal tersebut akan direspon positif oleh pasar sehingga dapat meningkatkan harga saham yang digunakan sebagai indikator nilai perusahaan.

Berdasarkan Sobel Test menunjukkan bahwa nilai t hitung $(0,735)$ lebih kecil dari t tabel $(1,667)$. Hasil penelitian ini menolak hipotesis ketujuh. Ketidakmampuan kebijakan dividen memediasi pengaruh free cash flow pada nilai perusahaan disebabkan oleh banyaknya perusahaan yang memiliki free cash flow negatif (sebanyak 52\% dari jumlah data amatan), sehingga proporsi kebijakan dividen bisa jadi menurun atau bernilai tetap. Karena tidak adanya peningkatan di dalam proporsi pembagian dividen, maka minat investor untuk berinvestasi menjadi lemah sehingga tidak dapat memengaruhi nilai perusahaan.

\section{SIMPULAN}

Berdasarkan hasil analisis yang diperoleh, disimpulkan bahwa investment opportunity set dan free cash flow berpengaruh positif pada kebijakan dividen; investment opportunity set, free cash flow dan kebijakan dividen berpengaruh positif pada nilai perusahaan; investment opportunity set berpengaruh pada nilai perusahaan melalui kebijakan dividen; dan free cash flow tidak berpengaruh pada nilai perusahaan melalui kebijakan dividen. 
Adapun saran yang dapat disampaikan terkait dengan penelitian ini adalah agar perusahaan agar mengambil keputusan investasi dan kebijakan dividen sesuai dengan kondisi keuangan perusahaan, sehingga optimalisasi nilai perusahaan yang merupakan tujuan utama perusahaan dapat tercapai. Selain untuk meningkatkan kemakmuran pemegang saham, juga untuk menjaga kelangsungan hidup perusahaan.

Nilai perusahaan merupakan tujuan jangka panjang suatu perusahaan. Oleh karena itu kesempatan investasi, free cash flow, dan kebijakan dividen periode-periode sebelumnya dapat digunakan sebagai predicator nilai perusahaan di masa depan. Sejalan dengan pengaruh positif antara investment opportunity set (IOS) pada kebijakan dividen, diduga terdapat kelemahan pada jumlah sampel. Oleh karena itu, penelitian selanjutnya diharapkan dapat memperluas jumlah sampel sehingga hasil akhir yang diperoleh sesuai dengan hasil yang diharapkan.

Sejalan dengan ketidakmampuan kebijakan dividen memediasi pengaruh free cash flow pada nilai perusahaan, penelitian selanjutnya diharapkan mencoba menggunakan variabel lain sebagai variabel mediasi, sehingga hasil akhir yang diperoleh sesuai dengan hasil yang diharapkan.

\section{REFERENSI}

Amihud, Y., \& K. Li. (2002). The Declining Information Content of Dividend Announcement and The Effect of Institutional Holding. FIN Working Paper No. 02-061 Stern School of Business, New York University.

Andini, Ni Wayan Lady, \&Ni Gusti Putu Wirawati. (2014). Pengaruh Cash Flow pada Kinerja Keuangan dan Implikasinya pada Nilai Perusahaan Manufaktur. E-Jurnal Akuntansi Universitas Udayana, 7(1), 107-121.

Arieska, Metha, \& Barbara Gunawan. (2011). Pengaruh Aliran Kas Bebas dan Keputusan Pendanaan terhadap Nilai Pemegang Saham dengan Set Kesempatan Investasi dan Dividen sebagai Variabel Moderasi. Jurnal Akuntansi dan Keuangan, 13(1), 13-23.

Astriani, Eno Putri. (2014). Pengaruh Kepemilikan Manajerial, Leverage, Profitabilitas, Ukuran Perusahaan dan Investment Opportunity Set terhadap Nilai Perusahaan. Skripsi. Sarjana Jurusan Akuntansi Fakultas Ekonomi Universitas Negeri Padang, Sumatera Barat.

Ayuningtias, Dwi, \& Kurnia. (2013). Pengaruh Profitabilitas terhadap Nilai Perusahaan: Kebijakan Dividen dan Kesempatan Investasi sebagai Variabel Antara. Jurnal Ilmu dan Riset Akuntansi, 1(1).

Brigham, E.F., \& J. Houston. (2001). Manajemen Keuangan. Penerjemah Hermawan Wibowo. Edisi Kedelapan. Edisi Indonesia. Buku II. Jakarta: Erlangga.

Chang, S.C, S.S. Chen, A. Hsing, \& C. W. Huang. (2007). Investment Opportunities, Free Cash Flow, and Stock Valuation Effects of Secured Debt Offerings. Review of Quantitative Finance and Accounting, 28(4), 123-145.

Chowdhury, Anup, \& Suman Paul Chowdhury. 2010. Impact of Capital Structure on Firm's Value: Evidence from Bangladesh. BEH - Business and Economic Horizons, 3(3), 111-122.

Chung, R., M. Firth, \& J. B. Kim. (2005). FCF Agency Costs, Earnings Management, and Investor Monitoring. Corporate Ownership and Control, 2(4), 51-61.

Crutchley, C., and R. Hansen. 1989. A Test of the Agency Theory of Managerial Ownership, Corporate Leverage, and Corporate Dividends. Financial Management, 18, 3646.

Delira, Novalia. (2007). Pengaruh IOS dan Manajemen Laba terhadap Nilai Perusahaan. Skripsi Universitas Negeri Padang, Sumatera Barat.

Easterbrook, F.H. (1984). Two Agency Cost Explanation of Dividends. American Economic Review, 74(4), 650-659.

Embara, Cecilia Triana Dewi Lestari, Ni Luh Putu Wiagustini, \& Ida Bagus Badjra. (2012). Variabel-variabel yang Berpengaruh terhadap Kebijakan Dividen serta Harga Saham pada Perusahaan Manufaktur di Bursa Efek Indonesia. Jurnal Manajemen, Strategi Bisnis, dan Kewirausahaan, 6(2).

Erlangga, Enggar. (2009). Pengaruh Kinerja Keuangan terhadap Nilai perusahaan dengan pengungkapan CSR, Good Corporate Governance, dan Kebijakan Dividen sebagai Variabel Pemoderasi. Skripsi. Fakultas Ekonomi Universitas Muhammadiyah Yogyakarta.

Fahmi, M. Lutfi Al, Amri, \& Sulaiman. (2014). Pengaruh Dukungan Perusahaan dan Kepemimpinan terhadap Kinerja Karyawan serta Dampaknya pada Kinerja PT. Bank Syariah Mandiri Cabang Langsa, Aceh. Jurnal Manajemen Pascasarjana Universitas Syiah Kuala , 3(1), 92-103. 
Fenandar, Gany Ibrahim, \& Surya Raharja. (2012). Pengaruh Keputusan Investasi, Keputusan Pendanaan, dan Kebijakan Dividen terhadap Nilai Perusahaan. Diponegoro Journal of Accounting, 1(2), 1-10.

Firdhayatin, Septy Kurnia, \& Nurul Hasanah Uswati Dewi. (2012). Analisis Nilai Perusahaan, Kinerja Perusahaan dan Kesempatan Bertumbuh Perusahaan terhadap Return Saham pada Perusahaan Manufaktur yang Listing di BEI. The Indonesian Accounting Review, 2(2), 203214.

Gaver, Jennifer J., \& Kenneth M. Gaver. (1993). Additional Evidence of The Association Between The Investment Opportunity Set and Corporate Financing, Dividend, and Compensation Policies. Journal of Accounting and Economics, 16, 125-160.

Gregory, Aand Yuan-Hsin Wang. (2010). Cash Acquirers: Free Cash Flow, Shareholder Monitoring, and Shareholder Returns. Discussion Paper No: 10/07. University of Exeter, UK.

Hasnawati, Sri. (2005). Implikasi Keputusan Investasi, Pendanaan, dan Deviden terhadap Nilai Perusahaan Publik di Bursa Efek Jakarta. Usahawan, (09).

Husnan, Suad. (2002). Dasar-dasar Teori Portofolio dan Analisis Sekuritas Edisi Ketiga. Yogyakarta : UPP AMP YKPN.

Jensen, M.C. (1986). Agency Cost of Free Cash Flow, Corporate Finance, and Takeovers. American Economics Review, 76. May 1986, pg: 232-329.

___ (1988). Takeovers: Their Causes and Consequences. Journal of Economic Perspectives, 2(1), 21-48.

Jensen, M., \& W. Meckling. (1976). Theory of the Firm: Managerial Behavior, Agency Cost and Ownership Structure. Journal of Financial Economics, 3, 305 - 360.

Kallapur, Sanjay, \& Mark A. Trombley. (1999). The Association Between Investment Opportunity Set Proxies and Realized Growth. Journal of Business \& Accounting.

Myers, S.C., (1984). The Capital Structure Puzzle. Journal of Finance, 39, 572-592.

Pratiska, Ni Gusti Ayu Putu Silka. (2013). Pengaruh IOS, Leverage, dan Dividend Yield terhadap Profitabilitas dan Nilai Perusahaan Sektor
Manufaktur di BEI. E-Jurnal Ekonomi dan Bisnis Universitas Udayana, (02) 03.

Puspitasari, Novia Ayu, \& Darsono. (2014). Faktorfaktor yang Berpengaruh terhadap Kebijakan Dividen. Diponegoro Journal of Accounting 3(2), 1- 8.

Rizqia, Dwita Ayu, Siti Aisjah, \& Sumiati. (2013). Effect of Managerial Ownership, Financial Leverage, Profitability, Firm Size, and Investment Opportunity on Dividend Policy and Firm Value. Research Journal of Finance and Accounting, 4(11).

Rosdini, Dini. (2009). Pengaruh Free Cash Flow terhadap Dividend Payout Ratio. Working Paper in Accounting and Finance.

Ross, S. (1977). The Determinant of Financial Structure: The Incentive Signaling Approach. Bell Journal of Economics. Spring: 23-40.

Smith, Richard L., \& Kim, Joo Hyun. (1994). The Combined Effects of Free Cash Flow and Financial Slack of Bidder and Target Stock Returns. Journal of Business, 67(2).

Sugiarto, Melanie. 2011. Pengaruh Struktur Kepemillkan dan Kebijakan Dividen terhadap Nilai Perusahaan dengan Kebijakan Hutang sebagai Intervening. Jurnal Akuntansi Kontemporer, 3(1), 1-25.

Suharli, Michell. 2007. Pengaruh Profitability dan Investment Opportunity Set terhadap Kebijakan Dividen Tunai dengan Likuiditas sebagai Variabel Penguat. Jurnal Akuntansi dan Keuangan, 9(1).

Sujoko, \& Ugy Soebiantoro. (2007). Pengaruh Kepemilikan Saham, Leverage, Faktor Intern dan Faktor Ekstern terhadap Nilai Perusahaan (Studi Empirik pada Perusahaan Manufaktur di Bursa Efek Jakarta). Jurnal Manajemen dan Kewirausahaan, 9(1), 41-48.

Szewcyzk, S. H., G. P. Tsetsekos \& Z. Zantout. (1996). The Valuation of Corporate R\&D Expenditures: Evidence from Investment Opportunities and Free Cash Flow. Financial Management, 25(1), 105-110.

Thanatawee, Y. (2011). Life-Cycle Theory and Free Cash Flow Hypothesis: Evidence Policy in Thailand. International Journal of Financial Research. 2(2).

Utama, Suyana. (2012). Aplikasi Analisis Kuantitatif. Denpasar: Universitas Udayana.

Vogt, Stephen C., \& Joseph D Vu. (2000). Free Cash Flow and Long-Run Firm Value : Evidence From 
The Value Line Investement Survey. Journal of Managerial Issues, 12(2), 188.

Wahyudi, U. dan H. P. Pawestri. (2006). Implikasi Struktur Kepemilikan terhadap Nilai Perusahaan: dengan Keputusan Keuangan sebagai Variabel Intervening. Simposium Nasional Akuntansi, 9 Padang, 1-25.

Wang, George Yungchih. (2010). The Impacts of Free Cash Flows and Agency Costs on Firm Performance. Journal Service Science \& Management. 3, 408-418, Department of International Business, National Kaohsiung University of Applied Sciences, Kaohsiung, Taiwan, China.
Wiagustini, Ni Luh Putu. (2010). Dasar-dasar Manajemen Keuangan. Edisi Pertama. Penerbit: Udayana University Press.

Wijaya, Lihan Rini Puspo, \& Anas Wibawa. (2010). Pengaruh Keputusan Investasi, Keputusan Pendanaan, dan Kebijakan Dividen terhadap Nilai Perusahaan. Simposium Nasional Akuntansi XIII Purwokerto 2010.

Wild, John J., Subramanyam, K. R., \& Halsey, R. F. (2007). Financial Statement Analysis, Ninth Edition, International Edition. Singapore: Mc. Graw Hill.

Wirjono, Endang Raino. (2009). Pengaruh Set Kesempatan Investasi terhadap Hubungan antara Kepemilikan Manajerial dan Aliran Kas Bebas dengan Tingkat Leverage Perusahaan. Kinerja, 13(1), 122-134. 